\title{
The Risks of Election Observation: International Condemnation and Post-Election Violence
}

\author{
Inken von Borzyskowski* \\ International Studies Quarterly (2019)
}

\begin{abstract}
Research on international election observation shows that observation reduces fraud, encourages participation, and boosts confidence in the election. However, this conventional account misses the negative, violence-inducing potential of observer criticism. This is the first study examining how observer criticism influences post-election violence. Democracy depends on the loser's consent, and the willingness of election losers to be governed by the winners can be influenced by observer criticism. When reputable observers criticize the credibility of an election, they can encourage losers to challenge the result. Observer criticism strengthens the electoral loser by legitimizing a challenge and serving as a focal point for mobilization. Using data on post-election violence in 38 countries in sub-Saharan Africa since 1990, I show that internationally condemned elections are more likely to turn violent than not-condemned elections. These results are robust to various control variables (including observer presence and election fraud) and to accounting for potential selection, spuriousness, endogeneity, and omitted variables.
\end{abstract}

*Assistant Professor, Florida State University; Email: i.Borzyskowski@fsu.edu Inken von Borzyskowski is the author of The Credibility Challenge: How Democracy Aid Influences Election Violence, which was published in summer 2019 by Cornell University Press. My thanks for excellent comments on previous versions go to Emanuel Adler, Jess Clayton, Jeff Colgan, Susan Hyde, Mert Kartal, Patrick Kuhn, Andy Kydd, Lisa Martin, Dave Ohls, Jon Pevehouse, Thomas Risse, Scott Straus, Michael Wahman, and to numerous audiences, including at ISA, EPSA, and European Peace Science. 
Virtually all countries today hold elections and most invite international observers to attend and judge their election credibility. Scholarship on election monitoring largely documents the positive effects of observers (Hyde 2007; Donno 2010 and 2013; Hyde and Marinov 2014; Flores 2012) while neglecting the potentially violent consequences of observer criticism. Outbreaks of violence followed negative observer verdicts on several elections, including Panama (1989), Cameroon and Mauritania (1992), Togo (1998), Nigeria (1999), Ethiopia (2005), Kenya (2007), Ivory Coast (2010), and Gabon (2015). So far, though, no study has examined the effect of observer criticism on election violence. While the criticismviolence effect is sometimes assumed to be established (Luo and Rozenas 2017), previous work examines the effect of observer criticism on protest (which may or may not be violent; Hyde and Marinov 2014) and the effect of observer presence and election fraud (Daxecker 2012; Smidt 2016). However, we do not know whether observer criticism drives violence. In particular, several major theoretical and empirical questions remain unanswered: is postelection violence the result of observer condemnation, observer presence, or election fraud? Further, how do elections derail after observer criticism: who has incentives to act on a negative observer verdict, and can we document this mechanism?

In this paper, I argue and show empirically that observer condemnation contributes to post-election violence. By issuing a negative verdict (i.e., alleging significant vote fraud), international monitors cast doubt on the credibility of the election. Such condemnation provides election losers legitimacy to challenge the election result and facilitates mobilization among the loser's supporters. Since more people are likely to come out and support the loser, the loser's chances of winning a potential post-election contest are heightened, thus making the loser more likely to challenge the result. Challenges by the electoral loser make it more likely that violence erupts. This paper specifies and tests the effect of observer criticism on post-vote violence and the mechanism of loser challenge.

I document the potentially violent consequences of observer condemnations, and disentangle the effect of observer criticism from the effects of observer presence and election fraud. I leverage data on post-election violence in 38 sub-Saharan Africa countries since 1990 in statistical analyses and a comparative case study. The analyses demonstrate that international condemnation can increase the risk of post-vote violence. Conditional on international observers attending, condemned elections are substantially more likely to be followed by violence than not condemned elections, especially in developing democracies. This result is robust to different fraud measures, a range of other controls, and to accounting for potential selection bias, omitted variables, endogeneity, and spuriousness. The effect of condemnation 
on post-vote violence is not simply driven by fraud; observer criticism exerts an additional, substantial effect. Fraud alone is less likely to lead to violence than "internationally certified fraud." Further, I document why condemnations increase the risk of violence: condemnations increase the risk that the loser will challenge the election results, which in turns makes violence more likely. Finally, I compare two similar elections (Kenya and Sierra Leone 2007), where different observer verdicts contributed to divergent outcomes. Taken together, these findings offer strong support for the argument that international condemnations can facilitate post-vote violence, and thus have negative side effects.

This paper identifies a key dilemma facing election observers who have hard evidence about manipulation. Observers can either endorse the fraudulent election, acting against their own mandate, or condemn it and risk violence. While observer groups do not aim to trigger violence, I show that their critical verdicts can contribute to unrest and instability. I disentangle the potential factors of observer criticism, observer presence, and fraud; I also outline policy implications for how observer groups may deal with this dilemma in practice. This paper addresses the unintended negative consequences of IOs for domestic politics, elections, and democracy promotion 11 By highlighting an international influence on post-vote violence, the paper moves beyond existing work on election violence, which is largely focused on domestic politics (fraud, competition, economics, civil war; see Flores and Nooruddin 2012; Bekoe 2012; Taylor, Pevehouse, and Straus 2017). About a quarter of elections worldwide are affected by electoral violence, which is often employed as a tool of political competition (Hafner-Burton, Hyde, and Jablonski 2014, 151; Fischer 2002, 11).

\section{Existing Research on Observation and its Effects}

International election observation has become widespread, with most developing countries inviting observers to monitor and assess their election's quality. Observer organizations vary in their reputability, which derives from their capacity to detect and their willingness to condemn manipulation (neutrality). Reputable observer groups invest more in the monitoring effort (e.g. number of staff and days present in country, being more systematic and professional) and are more likely to issue impartial assessments. Neutrality is highest for groups that are "disinterested third-party observers without a stake in the outcome of the election" (Hyde and Marinov 2014, 339).

${ }^{1}$ Other IO side effects are documented for human rights (Abouharb and Cingranelli 2006), civil war (Hartzell, Hoddie, and Bauer 2010), and rule of law (Simpser and Donno 2012). 
External observer groups are credible sources of information because they tend to be more neutral and nonpartisan than domestic or regional actors ${ }^{2}$ Domestic groups can have advantages in terms of larger staffing capacity and more local knowledge (Hyde 2011; Nevitte and Canton 1997). However, domestic groups may be less neutral in their assessments of elections because individual citizen observers and aggregate citizen groups usually have strong predispositions and a direct stake in the election outcome; they are not disinterested (Nevitte and Canton 1997, 50). Further, domestic groups can be more easily intimidated, curtailed, and their statements dismissed as having a pro-opposition bias..$^{3}$ Non-Western groups (i.e. regional membership organizations such as the African Union) are generally less neutral in their assessment because regional organizations are funded by member state governments, whose policy priorities may override democracy promotion. In addition, the level of democracy in regional member organizations (such as the African Union) is often mixed and relatively low, which makes these organizations less "vested in upholding electoral norms" (Kelley 2009, 770). This means regional organizations are not disinterested but instead tend to be biased in favor of governments, and at times rubber-stamp problematic elections (Institute for Security Studies 2017). Non-Western groups rarely condemn elections. 4

Reputable observer groups include - but are not limited to - the European Union (EU), the Carter Center (CC), the Commonwealth Secretariat, the National Democratic Institute (NDI), International Republican Institute (IRI), and International Foundation for Electoral Systems (IFES) (Carothers 1997, 21-22; Hyde 2011, 170; Hyde 2012, 40, 45, 50; Hyde and Marinov 2014, 343; Kelley 2012, 52-53, 120). That is, previous research deems "reputable" and "Western" as largely synonymous (Kelley 2009, 769-770; Hyde and Marinov 2012, codebook variables nelda46 and nelda47). I follow this convention and focus on reputable observer groups and criticism by such reputable groups.

Existing research has reached considerable agreement that external election observation overwhelmingly improves governance in host countries. External observers can detect and deter fraud (Alvarez et al. 2008, 211; Hyde 2007), increase participation of opposition

${ }^{2}$ Hyde and Marinov 2014, 339. For the same reasons, observers are more credible than non-observers such as governments, journalists, and foreign diplomats/individuals.

${ }^{3}$ Bjornlund 2004; Hyde and Marinov 2014, 338; Hyde 2011, 53. In line with this reasoning about domestic groups, Bush and Prather (2018) find that international observer verdicts can change election credibility, whereas domestic observers did not.

${ }^{4} \mathrm{I}$ control for the presence of domestic and non-Western groups in the robustness checks. 
parties (Bjornlund, Bratton, Gibson 1992, 408; McCoy, Garber, Pastor 1991, 109), encourage voter turnout (McCoy, Garber, Pastor 1991, 107), boost confidence in the announced result (Garber and Cowan 1993; McCoy, Garber, Pastor 1991, 112-113), and help raise the quality of current and future elections (Donno 2013, 101-104; Kelley 2012, 129, 154).5 Previous studies have examined which elections are more likely to be observed (Hyde 2011; Kelley 2012), to be fraudulent (Beaulieu and Hyde 2009; Hyde 2011, chapter 5; Hyde and O'Mahoney 2010; Schedler 2002; Simpser 2013; Simpser and Donno 2012), or to be condemned (Kelley 2009 and 2012). I build on insights from these previous studies, but shift the focus to a different aspect of the situation: namely, domestic reactions to observer statements $\sqrt[6]{6}$

Shortly after voting, observer organizations issue press statements and reports about the credibility of the electoral process and by implication its result. Observer press statements have become a media spectacle, with observer groups usually rushing for attention around election-day.7 International observers "maintain excellent contacts with international news media" (Hyde and Marinov 2014, 338). Domestic and international media eagerly attend observer press conferences and disseminate observer verdicts widely. Local, national, and international newspapers, radio, and other mass media (social media and television) also disseminate observer statements. Observer verdicts are well known among domestic actors, and "many domestic audiences such as opposition political parties cite observer reports as credible evaluations of the quality of elections" (Hyde 2012,41). The vast majority of critical reports reach mass audiences in the host country. Data indicate that in $93 \%$ of condemned elections, reports critical of the government's handling of the election reached large numbers of people. 8

${ }^{5}$ Some have raised caveats about the extent of these positive effects (Kelley 2012, 168169; Carothers 1997, 20-27) and noted strategic adaptation by the incumbent (Simpser and Donno 2012; Ichino and Schündeln 2012; Hyde and O’Mahony 2010).

${ }^{6} \mathrm{I}$ account for factors driving observation, condemnation, and whether elections are fraudulent in the empirical analyses.

${ }^{7}$ I document this in Appendix Figure A1 on the timing of reports.

${ }^{8}$ Variable nelda28 from Hyde and Marinov 2012. In the remaining $7 \%$ of elections, it is either unclear or the critical report did not reach large numbers. One example is Equatorial Guinea in 2008, which was an autocratic regime in which domestic media was heavily biased. I control for the level of democracy and whether critical reports reached the mass public in the main analysis and robustness checks. 
When monitors issue negative verdicts, they allege that the election was marred by serious fraud and thus violated democratic standards. Recent studies point to the positive effects of such condemnations: they make external enforcement of democratic norms more likely (Donno 2010, 615-616), they create moments of potential democratic revolutions (Beissinger 2007, 263), and they also increase the likelihood of protests (Chernykh and Svolik 2015, 417; Hyde and Marinov 2014, 329) which potentially helps self-enforcing democracy.

Yet regardless of protests' eventual fate, protests come at a price. Post-election protests often result in violence, especially in developing countries (Beaulieu 2014, 92). If condemnations also contribute to post-vote violence, then their effects can be detrimental to democratic stability and domestic peace. Some research has hinted at a condemnation-violence link (Kelley 2009, 771; Hyde 2011, 8) or assumed it as given (Luo and Rozenas 2017) but this link has not been systematically documented until now.

Systematically examining the violence-boosting potential of observer criticism is a corrective to existing research. Attitudinal studies on two elections have shown that observer criticism makes electoral losers more likely to believe the election result was not credible (Robertson 2017; Bush and Prather 2017); yet whether and how that translates into behavior remains an open question. Two other studies have shown that observer presence at fraudulent elections can increase the number of conflict events (Daxecker 2012; Smidt 2016). Sometimes it remains unclear whether conflict events are violent or election-related 9 More importantly, while the studies point to the theoretical importance of observer criticism, neither study empirically examines observer criticism 10 Instead, these studies examine observer presence at manipulated elections, which is not the same as observer condemnation. This is highlighted by the fact that fewer than half of flawed, observed elections are condemned. ${ }^{11}$

${ }^{9}$ Social Conflict in Africa Database (SCAD) data used in Smidt's study include nonviolent events, such as vandalism and newspaper raids (Smidt 2016, 232), which are not necessarily generating fatalities or injuries. Armed Conflict Location and Event Data Project (ACLED) data do not allow objectively filtering out electoral from other forms of violence, such as non-electoral protests, militia fights over territorial control, and peace campaigns. For another discussion of election violence data, see Taylor, Pevehouse, and Straus 2017, 401-403; and von Borzyskowski and Wahman 2019.

${ }^{10}$ Daxecker (2012, footnote 25$)$ states that observer fraud reports are not measured. Smidt (2016, 232-33) uses identical data.

${ }^{11}$ Only 41 percent of observed elections with serious fraud are condemned by observers. Author's calculation based on the fraud measure used in these articles, i.e. State Department 
Thus, observer presence at flawed elections is not a proxy for observer condemnation or observer criticism.

This article distinguishes the effect of observer condemnation from observer presence and election fraud. It therefore differs from most research on post-vote conflict in its explicit focus on observer statements rather than their mere presence, and whether negative verdicts - issuing critical statements about election quality - influence election violence. Moreover, I theorize and document the mechanism by which observer condemnations can trigger postvote violence. Electoral losers and how they choose to respond to a negative verdict are crucial to understanding when and why post-vote violence occurs.

\section{The Risk: Violent Consequences of Condemnations}

Democracy depends on the loser's consent. An often substantial portion of citizens who are displeased with the election outcome must agree to be governed by the winner rather than challenge the result. Election losers are critical because they "decide whether to fight on" or comply with adverse results (Riker 1983, 62; Przeworski 1991, 15; Nadeau and Blais 1993, 553). Election losers have incentives to challenge election results and risk or incite violence because they have the most to gain from a change in the status quo of political leadership. In contrast, the winner usually has few incentives to challenge election results or resort to force without a provocation. Note that the electoral loser can be either the incumbent or the opposition ${ }^{12}$ While it is possible for political leaders and supporters to disagree about the best path forward, leaders in many African elections have a strong influence and a party youth wing to implement violence when instructed (Laakso 2009, 231-232, 243-244; Mehler 2007, 204-206; Makumbe 2002, 91; Masunungure 2011, 55-57). In the case of the incumbent, the means of violence also include police and military.

The loser's consent has become habitual political behavior in advanced democracies ${ }^{13}$

Human Rights reports, which frequently reference US and non-US criticism and are issued up to a year after the election (see Daxecker 2012, 510; Smidt 2016, 232-233; data from Kelley 2010 QED).

${ }^{12}$ I return to this issue in the research design. The incumbent loses one in five African elections. The risk of post-vote violence is not significantly different in those cases; author's calculation based on data from Nelda and AEVD, described below.

${ }^{13}$ In the rare cases where election results are contested in advanced democracies, challenges usually take the form of legal proceedings (e.g. US 2000). 
but in many nascent democracies this is not the case. Here, losers constitute a "weak link in the chain of stable democratic governments" and the usual winner-loser gap in perceptions of legitimacy is wider (Anderson et al. 2005, 109, 101-104). In Africa in particular, losers often denounce elections and are less inclined to consent to government authority. (Lindberg 2006, 48; Moehler 2009, 345). Yet many elections remain peaceful, even in less democratic countries. Why does violence erupt after some elections but not others?

I propose an explanation centered on the role of international observer reports. Election observers can strengthen the loser by issuing a negative verdict, i.e. casting doubt on the credibility of the election. While the wording of negative reports varies, they mostly allege significant fraud and state one of the following:14 "elections have fallen short of key international and regional standards for democratic elections;" "significant manipulation" or "evidence of widespread manipulation." The IO observer's decision to condemn an election usually requires substantial evidence that egregious manipulation has occurred (Carothers 1997, 23-25; Hyde 2012, 53). Consequently, when reputable IO monitors do condemn elections, this public statement is a strong signal of manipulated results. Observer reports of fraud play an important role beyond fraud itself because reports provide information, reduce uncertainty about the level of fraud and incumbent popularity, tend to be more reliable than domestic allegations of fraud, and reach wide sections of the population (Chernyk and Svolik 2015; Hyde and Marinov 2014).

Condemnation by a reputable observer group can contribute to violence. One critical report can fuel violence (by increasing the loser's incentives to challenge the result), even when other observer groups disagree. This builds on previous work which showed that "criticism by one internationally reputable group is usually sufficient to cast doubt on the quality of the process," serve as a focal point for collective action, and legitimize post-election protests (Hyde and Marinov 2014, 337, 343). Politicians focus on and/or highlight observer statements that support their perspective (Kelley 2012, 48, 164; Kelley 2009, 62; Hyde and Marinov 2014). Complexity (or having multiple and sometimes conflicting reports) means that competitors get to pick the verdict that most supports their case. This implies that condemnations should be associated with more violence, regardless of whether other observer groups disagree. ${ }^{15}$

Condemnations strengthen the electoral loser in two ways: (1) by revealing that the

${ }^{14}$ These are examples from negative observer reports in the sample; similar examples can be found in Hyde 2011, 111.

${ }^{15} \mathrm{I}$ assess this in the robustness section. 
true level of the loser's popular support is likely higher than the official election result suggests, and (2) by serving as a focal point for mobilization among the loser's supporters. First, an international condemnation indicates that the loser is likely stronger than the officially announced result suggests. Since manipulation is usually in favor of the winner ${ }^{16}$ this suggests that the losing candidate's actual vote share and support are higher than the official results. Popular strength at the ballot box and in the street are linked "in the sense that people who vote for a party are also more likely to fight for the same party" (Londregan and Vindigni 2006, 25; Chacon, Robinson, and Torvik 2011). Vote shares reflect an actor's popularity and capacity, and thus indicate the potential for mobilization (Bunce and Wolchik 2010; Magaloni 2010).

Second, a condemnation can serve as a focal point for coordination and help crystallize support behind the loser in favor of overturning the result. Although supporters prefer standing by their candidate, their individual cost of rebellion potentially involves violence and state repression, which need to be weighed against the probability of success. Thus from the supporters' perspective, judging the legitimacy of the potential challenge is critical. An international verdict helps supporters distinguish between political cheap talk and the truth. The exposure of fraud can change an individual's calculus about participating in rebellions (Tucker 2007; Przeworski 1991). In particular, exposure of fraud can facilitate mobilization by lowering individual's cost of punishment and increasing the likelihood of success (Kuntz and Thompson 2009, 256-257; Kuran 1995, 247). A negative IO report shifts the candidate's probability of winning a post-election fight in favor of the loser by increasing the number of people who are willing to fight for the loser. If the loser is more likely to win a potential fight, the loser is more likely to risk a fight by challenging the result.

International condemnations can help electoral losers solve collective action problems. The loser's camp may then (1a) initiate violence or (1b) initiate peaceful protests (verbal, legal, in the streets), which can lead to (2) the winner cracking down and initiating violence. ${ }^{17}$ I argue that condemnations increase the risk of a loser challenge, contributing to violence

${ }^{16}$ Most manipulation is executed by incumbents and most incumbents win elections. Gandhi and Lust-Okar 2009, 412; Simpser 2013, 76; Beaulieu and Hyde 2009, 400-402.

${ }^{17}$ Empirical example cases include respectively: (1a) Kenya 2007; (1b) verbal announcement in Nigeria 2003; legal proceedings in Uganda 2011, Zimbabwe 2002, Cameroon 1992; loser peaceful street protest in Niger 1996, Equatorial Guinea 1999, Cameroon 1997; and (2) winner repressing the loser's peaceful protests in Ethiopia 2005, Togo 1998, Mauritania 1992. 
through one of two main scenarios. Either the loser's challenge is peaceful and the winner reacts violently to that challenge; or the loser's challenge itself is violent, and the winner reacts to that challenge violently. Empirically, both sides are often engaged in post-election violence 18 Concededly, it makes a difference whether losers turn violent or whether winners attack peaceful protesters. However, in the second scenario winners tend to react to the initial loser challenge, which itself would have been less likely without a condemnation. Regardless of the stage at which violence breaks out, the overall risk of violence should be higher after condemned elections. Consequently, I argue that condemnations encourage losers to challenge the result, which can then become violent.19 Taken together, I expect that condemnations increase the risk of post-vote violence. Observer criticism exerts an additional effect on violence, beyond the mere presence of observers or election fraud. Thus the following is the hypothesis that I test as the key observable implication.

\section{Hypothesis: International condemnation increases the likelihood of post-election violence.}

This hypothesis stands in contrast to alternative expectations about no effect or a violence-reducing effect. Some might think that condemnation may lower post-election violence because condemnation possibly generates higher international attention that (a) might make the winner less likely to use violence, and (b) might make the loser think that the international community will step in and thus might make violence less necessary ${ }^{20}$ However, this seems unlikely for two reasons. First, it is unclear why the winner would be less likely to use violence after condemnation. The winner has already been publicly shamed (condemned) for significant interference in the election. Moreover, if incumbents significantly manipulate elections, they likely value office holding more than the potential cost of international shaming. Both suggest that adding more shaming should not alter the behavior of winners. Second, losers are unlikely to believe that the international community might step

\footnotetext{
${ }^{18}$ Of all cases with post-election violence in the AEVD data (from Straus and Taylor 2012, described below), the incumbent is a major perpetrator in $94 \%$; the opposition is a major perpetrator in $44 \%$ and in an additional $25 \%$ the opposition is a minor perpetrator, for a total of $69 \%$. I thank Scott Straus and Charlie Taylor for sharing these data with me.

${ }^{19}$ For empirical evidence of the link between condemnations, loser challenge, and violence, see Supplementary Files, Tables A4 and A5.

${ }^{20} \mathrm{I}$ thank a reviewer for raising this point.
} 
in after condemnations because outside interventions to overturn election results are exceedingly rare. In only $7 \%$ of elections did an outside actor attempt to influence the election outcome (variable nelda58 from Hyde and Marinov 2012) and most of this influence occurs before voting takes place (Bubeck and Marinov 2017, 537). Furthermore, even if outside intervention after voting were to take place, it would likely encounter opposition by other international powers, as different interveners might support different candidates (Risse and Babayan 2015; von Soest and Wahman 2015). While a violence-reducing effect thus does not seem likely, it nonetheless serves as a potential counter-argument to the main hypothesis proposed here, i.e. that condemnation facilitates post-election violence.

\section{Research Design}

I test the hypothesis using data from 1990 to 2008 for national elections in 38 countries in sub-Saharan Africa. The unit of observation is national elections, which includes legislative, presidential, and general elections. This geographic region is suitable for several reasons. A cross-national analysis of sub-Saharan Africa allows me to compare countries with a similar trajectory because most of them transitioned to multi-party rule in the early 1990s. The region also offers significant variation in both the dependent variable (violence) and the key independent variable (condemnation). Further, as a practical matter sufficiently granular data exist on Africa to test my argument here ${ }^{21}$

The main dependent variable is electoral violence (physical force) in the three months after each national election 22 Post-election violence is 1 if at least one election-related fatality occurred. This can take the form of assassination (i.e. at least 1 death) combined with long-term high-level arrests of party leaders, the consistent use of violent harassment or torture; or it can take the form of widespread physical attacks resulting in more than 20 deaths (Straus and Taylor 2012, 21-22; Taylor, Pevehouse, and Straus 2017 - African Electoral Violence Database, AEVD). The variable is zero when no fatality was reported and for minor harassment short of violence (e.g. police breaking up rallies, street brawls, opposition newspapers being confiscated, candidate disqualifications). Unless noted otherwise, I

\footnotetext{
${ }^{21}$ Other data do not measure violence (but protest, conflict), do not distinguish the electoral dimension of the violence (but capture general civil conflict), or do not distinguish violence before versus after election-day.

${ }^{22}$ The three-month period is standard in studies on post-election conflict (Daxecker 2012; Straus and Taylor 2012, 19-20; Smidt 2016; von Borzyskowski 2019).
} 
estimate binary logit models with robust standard errors clustered by country to adjust for the lack of independence of elections within the same country.

In addition to examining the main effect - that of condemnation on post-election violence - I also assess the plausibility of steps in the proposed causal chain, involving loser challenges. Recall that the loser can be either the incumbent or the opposition, so that the proposition should be tested with data on loser challenges. The variable loser challenges is coded 1 when some or all electoral losers rejected the election result or consented only after substantial delay. Consenting only after substantial delay is coded as a loser challenge because the results of the election are challenged for some time (often several weeks) before the loser consents, which leaves a substantial window of time for protests, unrest, and violence to emerge. It is coded 0 when all main players immediately accepted the announced result, i.e. right after results are announced.23

The key independent variable is international condemnation in the form of a negative observer report or press release. This variable is a binary indicator coded 1 when any reputable IO observer group seriously questioned the process or outcome of the election ${ }^{24}$ Following prior research, reputable IO observers are operationalized as Western groups, including the European Union (EU), European Parliament, the Carter Center, the National Democratic Institute (NDI), International Republican Institute (IRI), Commonwealth Secretariat, and International Foundation for Electoral Systems (IFES).25

To distinguish the effect of observer criticism from observer presence, I include the variable IO observers present. This is coded 1 when Western IO monitors observed the election and 0 otherwise (variable nelda46). Based on this variable, I analyze two sets of elections: (i) the full universe of elections, controlling for observer presence and (ii) the restricted sample of observed elections. The latter offers a more stringent, cleaner test of the argument because only those elections are included in the analysis which "qualify" for observer condemnation in the first place.

To distinguish the effect of observer fraud reports from fraud itself, I include indicators of

${ }^{23}$ Data from Lindberg 2006; the shorter temporal coverage reduces the number of observations.

${ }^{24}$ I use variable nelda47 from Hyde and Marinov 2012, which has been used previously for the same purpose (Hyde and Marinov 2014).

${ }^{25}$ When controlling for conflicting reports by multiple attending Western groups or any observer groups, results are qualitatively similar; see Supplementary Files, Tables A6-A7. 
fraud on and before election day ${ }^{26}$ Since fraud is not perfectly observable, I use six alternative measures of fraud to capture presence and severity from multiple sources. This includes a measure of concerns before the elections that elections will not be free and fair, which captures fraud expectations and is not influenced by observer reports or other aspects known after election-day. ${ }^{27}$ The four-point scale fraud election-day level measures no, minor, moderate, and major issues with vote fraud or intimidation, while the binary variable fraud election-day dummy specifically indicates major problems ${ }^{28}$ Since the source of these particular variables ends in 2004 (reducing sample size), I supplement missing values from fraud election-day dummy with more recent data on major vote fraud and intimidation ${ }^{29}$ to generate the variable serious fraud. In the robustness checks, I use three additional fraud measures for the period before elections and overall manipulation; the results are quite similar ${ }^{30}$

A first look at the raw data provides tentative support for the hypothesis that the risk of post-election violence is significantly higher after condemnations. Figure 1 shows the rate of post-election violence for observed elections in 38 sub-Saharan African countries between 1990 and 2008. Figure 1 panel (a) is a bivariate comparison between violence and condemnation. It illustrates that 25 percent of all condemned elections experienced violence afterwards but only 6 percent of elections turned violent when they were not criticized by international observers. This difference of 19 percentage points is statistically significant. ${ }^{31}$ Figure 1 panels (b) and (c) show that the violence gap exists regardless of whether serious

${ }^{26}$ For fraud and post-election mobilization, see Kuntz and Thompson 2009; Tucker 2007.

${ }^{27}$ See prior fraud concerns in model 2 of Tables A9-A10. This is a cleaner measure than some of the other fraud variables, which may be influenced by aspects known after the election, including observer reports.

${ }^{28}$ Kelley 2010, QED sr21cheat, which is based on U.S. State Department human rights reports. While State Dept reports provide a useful measure of election fraud (and are thus used in this analysis), they cannot cause violence in the immediate post-election period because State Dept reports are written and published in the year after the election. Using separate dummies for the different levels shows that major fraud is the aspect most associated with violence.

${ }^{29}$ Beck et al. 2001. This is a binary indicator recording "whether vote fraud or candidate intimidation [were] serious enough to affect the outcome of elections" (DPI 2012, 17).

${ }^{30}$ See Supplementary Files, Tables A9 and A10.

${ }^{31}$ Difference of proportions test yields $\mathrm{p}=0.00$. 
fraud occurred: post-vote violence is between two and seven times more likely to follow condemned than non-condemned elections. ${ }^{32}$ Even in the absence of serious fraud, the effect of a negative report is substantively important, doubling the risk of post-election violence. This initial comparison suggests that condemnations and post-election violence are strongly related.

Figure 1: Rates of Post-Election Violence, by Condemnations and Fraud
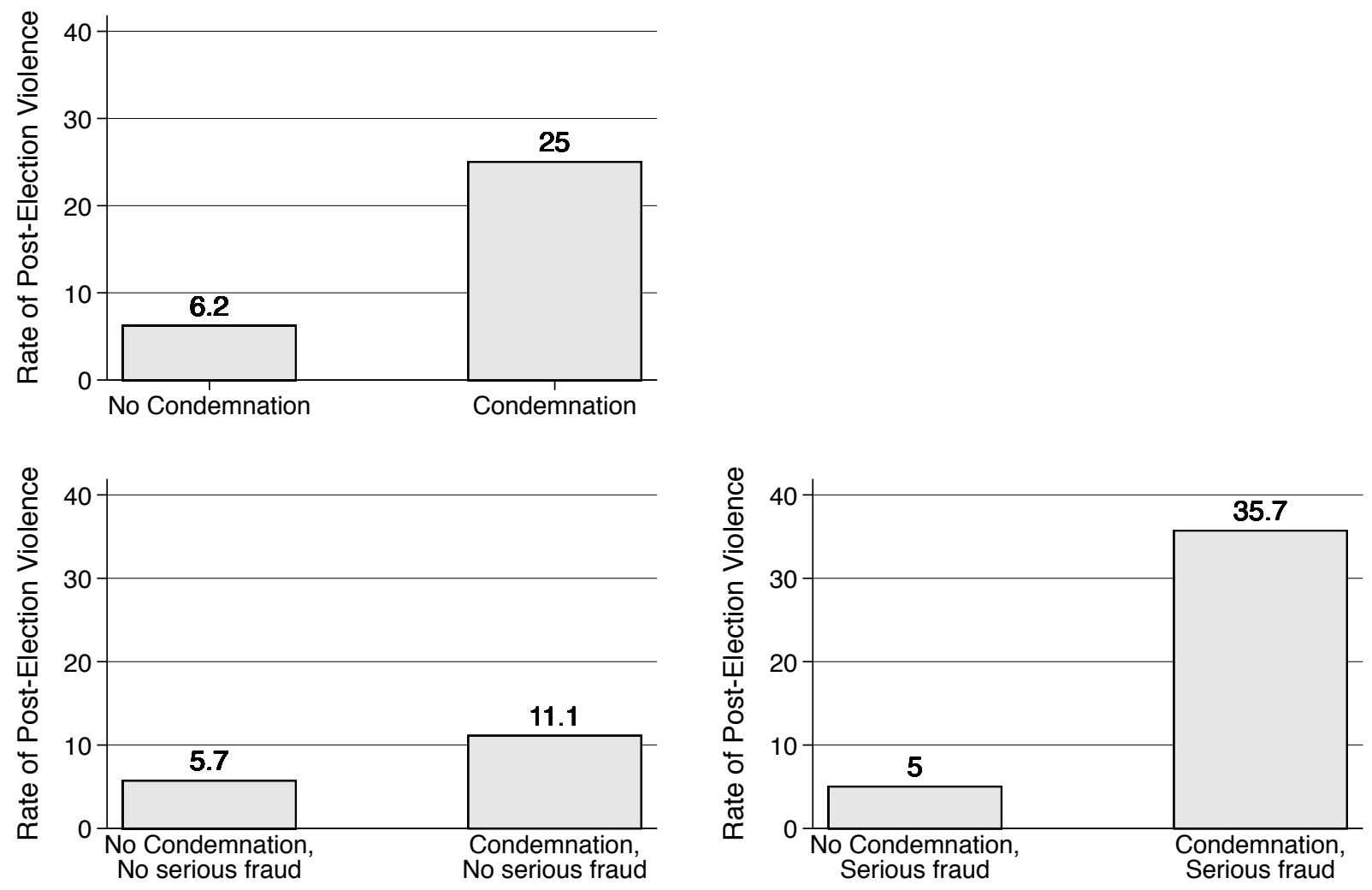

In addition to fraud, I control for several other election-level variables which prior research has identified as correlates of post-election conflict, such as vote shares and opposition boycotts (Arriola and Johnson 2012, 41; Beaulieu 2014, 73). Loser's vote share is the percentage points for the runner-up, according to official election results. ${ }^{33}$ I expect greater

${ }^{32}$ Difference of proportions test yields $\mathrm{p}=0.02$ in the case of serious fraud.

${ }^{33}$ Data from Carr 2012; Nohlen, Krennerich, and Thibaut 1999; African Elections Database. For general elections I use presidential results; for two-round elections I use sec- 
popular support for the loser to increase the loser's incentives to challenge results and thus increase violence risks. In addition, more popular losers might also face more government crackdown in reaction to the challenge or as an attempt to prevent it. A binary control for opposition boycotts is included, which should also be positively associated with post-election violence when dissatisfaction from the campaigning period spills over into the post-election phase (variable nelda14). The models also control for pre-election violence level, a four-point scale of election-related violence in the six-month campaigning period before elections. ${ }^{34}$ Lastly, poll type distinguishes between legislative (0), executive (1) and general elections $(2) .55$

The models also include a range of country-level controls to account for context and remote causes of violence. These are leader tenure and executive constraint 56 which influence conflict dynamics (Krieger 2005; Hafner-Burton, Hyde, and Jablonski 2014; Fearon and Laitin 2003). The models also include GDP per capita for economic development (Collier 2009, 20-21) 37 and natural resources per capita for unearned oil and gas income (Ross 2012; Fearon and Laitin 2003) ${ }^{38}$ Population siz ${ }^{39}$ and ethnic fractionalization are included as demographic controls (Finkel, Perez-Linan and Seligson 2007; also see Wilkinson 2004). All of these country-level controls are lagged by a year so that they are not contemporaneous with the outcome and to mitigate endogeneity. ${ }^{40}$ Finally, post conflict measures whether the country experienced civil conflict in the previous ten years 41 Descriptive statistics for all

ond round results. Results are qualitatively similar to using the loser's seat shares instead of vote shares.

${ }^{34} \mathrm{AEVD}$ previolev; results are qualitatively similar with a binary variable.

${ }^{35}$ AEVD type. Elections occurring within three months of each other are collapsed to one observation because it is difficult (if not impossible) to distinguish whether electoral violence relates to one or another temporally close election.

${ }^{36}$ Data are from Beck et al. 2001 (logged); Marshall and Jaggers 2011.

${ }^{37}$ Measured in constant USD and logged. See World Bank 2012.

${ }^{38}$ Logged value of oil and gas production to a government once subsidies are accounted for.

${ }^{39}$ Measured in millions and logged. World Bank 2012.

${ }^{40}$ Follow-up analyses also account for potential endogeneity; see below.

${ }^{41}$ Gleditsch et al. 2002, (internationalized) internal armed conflict. Using alternative specifications of the time period (one and five years after civil war) does not affect results. 
variables are in Table A1 in the Supplementary Files.

\section{Results}

Table 1 presents the estimated impact of condemnation on post-election violence. The results consistently support the main argument. The coefficient on condemnation is positive and statistically significant in all models $(p<0.05)$. Columns 1 through 3 are estimated on all elections, so that the counterfactual to condemnation includes both other ${ }^{42}$ observer verdicts and unobserved elections; I control for whether monitors were present. The mere presence of observers by itself is not a significant predictor of post-vote violence. This casts doubt on the assumption that the mere presence of monitors, on average, may reduce postelection violence (Luo and Rozenas 2017). Columns 4 through 6 offer a more conservative, cleaner test of the hypothesis since the sample is restricted to observed elections only. Here the counterfactual to condemnation is non-negative observer verdicts (i.e. positive and mixed reports). Throughout all models, observer condemnation is associated with a significantly higher risk of post-election violence ${ }^{43}$

If condemnations (negative reports) can exacerbate violence, an interesting question is whether endorsements (positive reports) can deter violence. Recall that the counterfactual in models 4-6 includes both positive and mixed reports, so we cannot infer from Table 1 whether endorsements have any effects. To assess this possibility, I use supplementary data to code the variable endorsement, i.e. clearly positive reports (not negative or mixed observer verdicts). I replicate Table 1 with endorsement instead of condemnation. ${ }^{44}$ This reveals that endorsement is associated with less violence but the estimates are based on a much smaller sample of elections (due to data availability) so that results remain suggestive.

The effect of condemnations is also substantively important. Figure 2 shows changes in the predicted probability of post-election violence when condemnation is varied from 0 to 1 in

${ }^{42}$ Condemnations are significantly different from other verdicts; see Supplementary Files page 2.

${ }^{43}$ Robustness checks replace the violence measure (based on AEVD) with alternate outcome measures (SCAD and ACLED). The results are substantively similar. The coefficients on condemnation are positive in all models and statistically significant in most models. Details are in the Appendix pages 5-7, Appendix Tables A4 and A5.

${ }^{44}$ Data from Kelley 2010, DIEM data, variable a1. Table not shown but code included in the replication file. 
Table 1: Effect of Condemnation on Post-Election Violence

\begin{tabular}{|c|c|c|c|c|c|c|}
\hline & \multicolumn{3}{|c|}{ All elections } & \multicolumn{3}{|c|}{ Observed elections only } \\
\hline & (1) & $(2)$ & $(3)$ & $(4)$ & $(5)$ & $(6)$ \\
\hline Condemnation & $\begin{array}{c}2.934^{* * *} \\
(0.914)\end{array}$ & $\begin{array}{c}3.335^{* *} \\
(1.475)\end{array}$ & $\begin{array}{c}3.157^{* *} \\
(1.575)\end{array}$ & $\begin{array}{c}3.621^{* * *} \\
(1.321)\end{array}$ & $\begin{array}{c}6.570^{* *} \\
(2.765)\end{array}$ & $\begin{array}{c}6.964^{* *} \\
(3.201)\end{array}$ \\
\hline \multicolumn{7}{|l|}{ Election controls } \\
\hline IO observers present & $\begin{array}{c}-0.407 \\
(1.054)\end{array}$ & $\begin{array}{l}-1.058 \\
(1.097)\end{array}$ & $\begin{array}{c}-0.985 \\
(1.142)\end{array}$ & & & \\
\hline Serious fraud & $\begin{array}{l}1.764^{* *} \\
(0.828)\end{array}$ & & & $\begin{array}{c}1.223 \\
(0.806)\end{array}$ & & \\
\hline Fraud election-day dummy & & $\begin{array}{c}2.135^{* *} \\
(0.945)\end{array}$ & & & $\begin{array}{c}1.799 \\
(1.697)\end{array}$ & \\
\hline Fraud election-day level & & & $\begin{array}{c}1.219^{* *} \\
(0.548)\end{array}$ & & & $\begin{array}{l}0.891^{*} \\
(0.468)\end{array}$ \\
\hline Loser's vote share & $\begin{array}{c}0.075^{* * *} \\
(0.023)\end{array}$ & $\begin{array}{c}0.076^{* * *} \\
(0.029)\end{array}$ & $\begin{array}{c}0.085^{* * *} \\
(0.030)\end{array}$ & $\begin{array}{c}0.105^{* * *} \\
(0.034)\end{array}$ & $\begin{array}{c}0.169 \\
(0.117)\end{array}$ & $\begin{array}{l}0.165^{*} \\
(0.094)\end{array}$ \\
\hline Boycott & $\begin{array}{c}0.873 \\
(1.255)\end{array}$ & $\begin{array}{c}1.608 \\
(1.670)\end{array}$ & $\begin{array}{c}1.483 \\
(1.560)\end{array}$ & $\begin{array}{c}1.850 \\
(1.355)\end{array}$ & $\begin{array}{c}6.541 \\
(4.080)\end{array}$ & $\begin{array}{l}6.838^{*} \\
(3.543)\end{array}$ \\
\hline Poll type & $\begin{array}{c}0.032 \\
(0.625)\end{array}$ & $\begin{array}{c}0.601 \\
(0.592)\end{array}$ & $\begin{array}{c}0.584 \\
(0.662)\end{array}$ & $\begin{array}{l}-0.238 \\
(0.860)\end{array}$ & $\begin{array}{c}1.751^{* * *} \\
(0.515)\end{array}$ & $\begin{array}{c}1.891^{* * *} \\
(0.668)\end{array}$ \\
\hline Pre-election violence level & $\begin{array}{c}0.059 \\
(0.557)\end{array}$ & $\begin{array}{c}0.039 \\
(0.659)\end{array}$ & $\begin{array}{l}-0.201 \\
(0.894)\end{array}$ & $\begin{array}{l}-0.116 \\
(0.579)\end{array}$ & $\begin{array}{l}-0.369 \\
(0.544)\end{array}$ & $\begin{array}{l}-0.661 \\
(0.658)\end{array}$ \\
\hline \multicolumn{7}{|l|}{ Country controls } \\
\hline Leader tenure (log) & $\begin{array}{c}0.713^{* *} \\
(0.333)\end{array}$ & $\begin{array}{c}1.018^{* * *} \\
(0.378)\end{array}$ & $\begin{array}{c}0.927^{* *} \\
(0.454)\end{array}$ & $\begin{array}{c}0.777 \\
(0.524)\end{array}$ & $\begin{array}{c}1.116^{* *} \\
(0.520)\end{array}$ & $\begin{array}{c}0.968^{* *} \\
(0.443)\end{array}$ \\
\hline Post conflict & $\begin{array}{l}-1.528 \\
(1.369)\end{array}$ & $\begin{array}{l}-1.649 \\
(2.363)\end{array}$ & $\begin{array}{l}-2.014 \\
(2.184)\end{array}$ & $\begin{array}{l}-1.059 \\
(1.425)\end{array}$ & $\begin{array}{c}0.297 \\
(1.849)\end{array}$ & $\begin{array}{c}0.002 \\
(1.790)\end{array}$ \\
\hline GDP pc (log) & $\begin{array}{l}-1.021 \\
(0.816)\end{array}$ & $\begin{array}{l}-1.204 \\
(0.959)\end{array}$ & $\begin{array}{l}-1.062 \\
(0.872)\end{array}$ & $\begin{array}{c}0.043 \\
(0.671)\end{array}$ & $\begin{array}{c}1.192 \\
(1.093)\end{array}$ & $\begin{array}{c}1.329 \\
(1.099)\end{array}$ \\
\hline Natural resources pc (log) & $\begin{array}{c}0.025 \\
(0.089)\end{array}$ & $\begin{array}{c}0.116 \\
(0.100)\end{array}$ & $\begin{array}{c}0.104 \\
(0.109)\end{array}$ & $\begin{array}{l}-0.056 \\
(0.097)\end{array}$ & $\begin{array}{l}-0.028 \\
(0.121)\end{array}$ & $\begin{array}{l}-0.025 \\
(0.115)\end{array}$ \\
\hline Executive constraints & $\begin{array}{c}0.379 \\
(0.349)\end{array}$ & $\begin{array}{c}0.521 \\
(0.354)\end{array}$ & $\begin{array}{l}0.696^{*} \\
(0.371)\end{array}$ & $\begin{array}{c}0.340 \\
(0.519)\end{array}$ & $\begin{array}{c}0.802 \\
(0.720)\end{array}$ & $\begin{array}{c}0.887 \\
(0.728)\end{array}$ \\
\hline Population size (log) & $\begin{array}{l}-0.916 \\
(0.634)\end{array}$ & $\begin{array}{l}-1.160 \\
(0.749)\end{array}$ & $\begin{array}{l}-1.149 \\
(0.844)\end{array}$ & $\begin{array}{l}-0.821 \\
(0.776)\end{array}$ & $\begin{array}{c}-1.532^{*} \\
(0.787)\end{array}$ & $\begin{array}{c}-1.656^{*} \\
(0.967)\end{array}$ \\
\hline Ethnic fractionalization & $\begin{array}{l}-0.424 \\
(2.488)\end{array}$ & $\begin{array}{l}-3.272 \\
(2.337)\end{array}$ & $\begin{array}{l}-2.511 \\
(2.479)\end{array}$ & $\begin{array}{c}2.297 \\
(3.557)\end{array}$ & $\begin{array}{c}1.690 \\
(3.880)\end{array}$ & $\begin{array}{l}1.985 \\
(5.255)\end{array}$ \\
\hline Constant & $\begin{array}{c}0.039 \\
(6.243) \\
\end{array}$ & $\begin{array}{c}2.481 \\
(7.637)\end{array}$ & $\begin{array}{l}-0.562 \\
(5.975)\end{array}$ & $\begin{array}{c}-10.142^{*} \\
(5.952)\end{array}$ & $\begin{array}{l}-24.216 \\
(16.403)\end{array}$ & $\begin{array}{c}-25.702 \\
(15.857)\end{array}$ \\
\hline Observations & 151 & 114 & 114 & 109 & 83 & 83 \\
\hline Number of countries & 38 & 37 & 37 & 35 & 34 & 34 \\
\hline Percent correctly classified & 94.70 & 94.74 & 94.74 & 96.33 & 96.39 & 93.98 \\
\hline $\mathrm{ROC}$ & 0.87 & 0.89 & 0.91 & 0.89 & 0.95 & 0.96 \\
\hline Pseudo R2 & 0.34 & 0.36 & 0.38 & 0.40 & 0.49 & 0.49 \\
\hline $\mathrm{AIC}$ & 81.77 & 67.16 & 65.91 & 65.17 & 49.98 & 50.01 \\
\hline $\mathrm{BIC}$ & 127.03 & 108.20 & 106.96 & 102.85 & 83.85 & 83.88 \\
\hline LL & -25.89 & -18.58 & -17.96 & -18.59 & -10.99 & -11.01 \\
\hline
\end{tabular}

Notes: Logit models with standard errors clustered on country in parentheses.

${ }^{*} p<0.10,{ }^{* *} p<0.05,{ }^{* * *} p<0.01$

two fraud scenarios. When reputable monitors observe and condemn elections, the risk of a violent aftermath increases by 46 percentage points when election day was marred by serious 
fraud and 17 percentage points when it was not fraudulent.45 This effect is substantively important, as it represents a large shift in conflict risk and also exceeds the fraud effect. To compare the two effects, note that changes in serious fraud without a condemnation (5 percentage points) and with a condemnation (34 percentage points) are smaller than changes in condemnation (17 and 46 percentage points).

Figure 2: Substantive Effect of Condemnation on Post-Election Violence

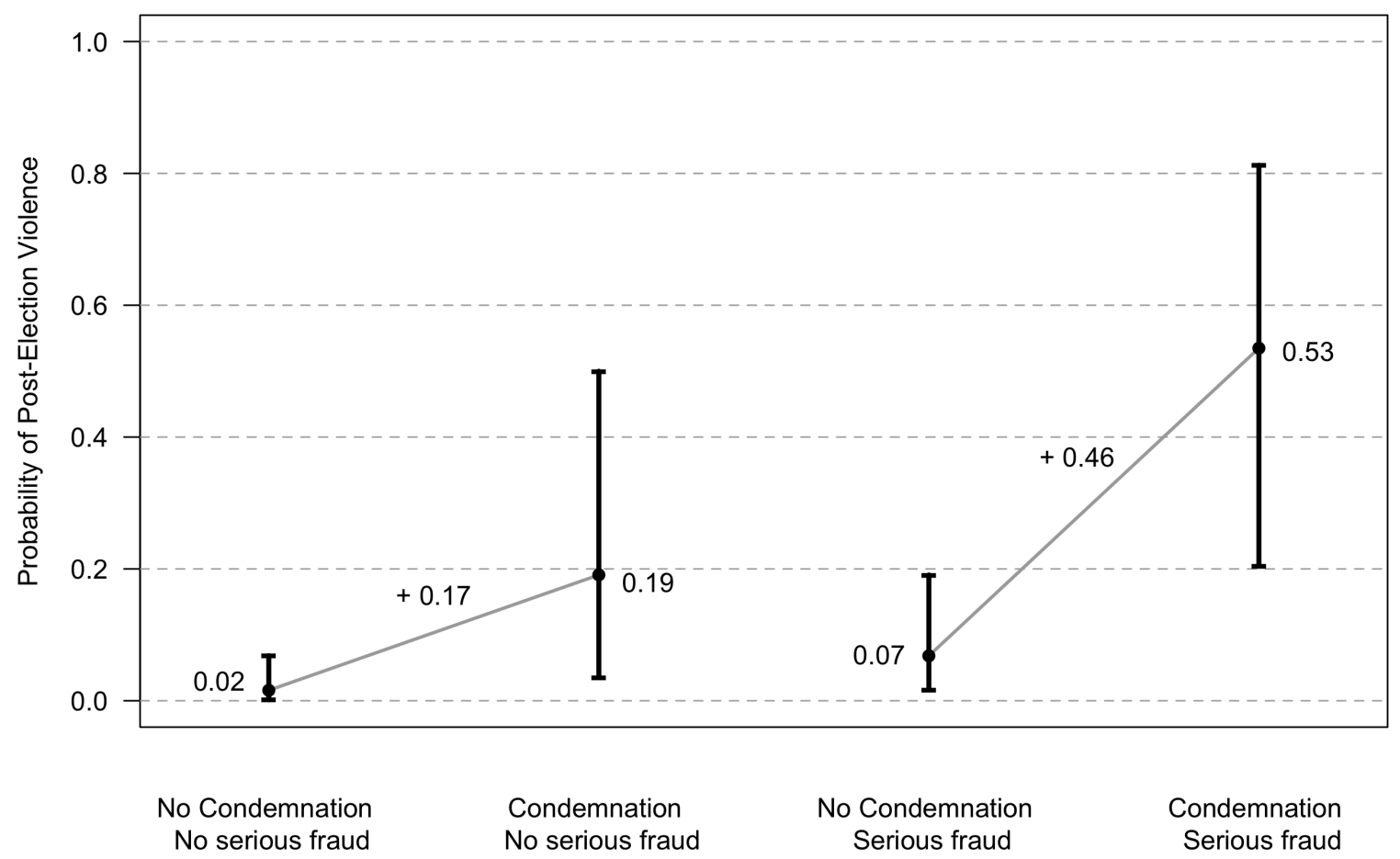

Figure 2 shows that the effect of observer condemnation on violence obtains regardless of election-day fraud and that the effect is smaller - but still substantial - when no such fraud occurred. Condemnations based on manipulation other than election-day fraud, e.g. the absence of a "level playing field" even before elections, are less likely to trigger violence. This is in line with the mobilization mechanism, since the attenuated effect is mainly driven by one type of political regimes: electoral autocracies. While countries in the group "condemnation with election-day fraud" have a variety of regime types, the group "condemnation without election-day fraud" is populated by countries which are almost all autocracies (e.g. Zimbabwe 2002, Uganda 2001 and 2006, Comoros 1996). Electoral autocracies stand out in two ways:

${ }^{45}$ Predicted probabilities are based on column 1 with control variables set to means/modes (i.e. observers present $=1$ ) and are calculated using Clarify (King, Tomz, Wittenberg 2000). 
they tend to frontload fraud to the pre-election period (so that serious election-day fraud is no longer necessary) and repress opposition movements (e.g. by limiting freedoms of expression and association).

The attenuated effect in electoral autocracies is consistent with the mobilization mechanism outlined above: for losers to challenge the result in the streets, they must have some potential for collective action and some prospect of success. However, in autocracies incumbents tend to win and the losing opposition usually stands little chance of either mobilization or successful turnover. The power disparity in electoral autocracies is so great that losers usually dare not violently challenge the regime (anticipating overwhelming state repression), and winners rarely need to use violence in reaction. Rather, loser challenges tend to take the form of verbal announcements, court petitions (as in Uganda 2001-2011 and Cameroon 1992) or peaceful demonstrations. ${ }^{46}$ These strategies tend to be countered by the winner through judicial decisions or short-term arrests, rather than escalating into months of fighting between two similarly powerful groups. Therefore, condemnations' effect on post-election violence is weaker in electoral autocracies than in other contexts (mainly developing democracies).

While the results support the argument that observer condemnations can contribute to violence, I do not claim that condemnations determine violence, are the single cause of violence, or that they are always the primary driver of conflict. Domestic variables underlying, sometimes long-term conditions - are also important. Fraud, the loser's vote share, and leader tenure are statistically significant and positively associated with violence. Further, in the subset of observed elections, executive and general elections are more prone to violence (likely because of the higher stakes), and those held in somewhat more populous countries are less prone to violence. The remaining control variables have no consistent effects. 47

The data also support the importance of loser challenges in the causal chain linking observer condemnations and violence. While my main interest is establishing the effect of condemnation on post-vote violence - and distinguishing it from the effects of observer presence or fraud - supplementary data are sufficiently granular to also examine the plausibility

${ }^{46}$ After Ethiopia's condemned 2005 election, the losing opposition challenged through peaceful demonstrations, which then met government crackdown; more than two-hundred people died.

${ }^{47}$ Campaign violence does not emerge as a significant predictor. This matches other research showing that pre- and post-election violence are two different phenomena, operating under distinct logics (Taylor, Pevehouse, and Straus 2017, 398, 406, 408-409). 
of the intermediary step in the causal chain and allow inferences about the behavior of the key actor, i.e. whether the electoral loser is more likely to challenge a result when it is condemned, which then triggers violence. Simple bivariate comparisons show that condemnations are associated with a 25 percentage point higher rate of loser challenges, and loser challenges in turn are associated with a 9 percent higher rate of post-election violence. These bivariate differences are statistically significant. For the multivariate analysis, I replicate Table 1 but replace the outcome variable with loser challenge. Table A2 in the Supplementary Files shows that condemnations are significantly associated with a higher risk of loser challenges, controlling for a range of other factors. That is, observed elections are significantly more likely to be challenged when they were condemned by observers. Loser challenges, in turn, are significantly associated with increased violence $(p<0.01)$, as shown in Table A3 in the Supplementary Files. In terms of substantive importance, loser challenges are associated with a 12 percentage point increase in post-vote violence ${ }^{48}$ These results support the causal chain outlined in the theory section, i.e. that condemnations increase the loser's incentives to challenge results, and that loser challenges increase the risk of violence after elections.

\section{Alternative Explanations}

The results support the argument that condemnations can contribute to post-election violence. However, it could be that the relationship is an artifact of selection, reverse causation, or spuriousness (e.g. simply driven by fraud). First, the relationship might be an artifact of selection. If observer groups attend more volatile elections, their condemnation would reflect these problems but such elections would have been violent independent of the condemnation. To explicitly test this concern, I use two-stage estimations, which model observer presence based on prior research (Hyde 2011, 77; see notes for Table A14 in the Supplementary Files). Heckman sample selection models show that even after controlling for potential observer selection, the results hold (see Table A11 in the Supplementary Files). In a different two-stage setup, I also test more explicitly whether observers tend to select into or withdraw prematurely from more violent elections but find no empirical support for these selection issues (see Tables A12-A13 in the Supplementary Files).

Another selection concern is that observer criticism is not random. Monitors often couch their concerns diplomatically and only condemn an election when they have hard evidence

\footnotetext{
${ }^{48}$ Based on model 2 of Table A3 in the Supplementary Files with all variables set to their means and modes.
} 
(Carothers 1997, 23-25; Hyde 2011, 110-112). Also, observers might be less likely to condemn if they think the propensity for post-election violence is high (Kelley 2012, 72-73). The latter logic should make it harder to find the effects that I find in Table 1 because it would mean that condemnations would be less likely in the most violence-prone elections. Nonetheless, the endogeneity of condemnations is worth addressing. I thus replicate model 4 of Table 1 but allow condemnations to be endogenous to several factors identified in prior research (Kelley 2012, 198; see notes for Table A14 in the Supplementary Files), including fraud and pre-election violence. The first stage is whether a negative report is issued, and the second stage is identical to the main analyses. The results show that even when accounting for the drivers of condemnation, condemnation remains significantly associated with a higher risk of violence (Table A14 in the Supplementary Files).

A second concern is that causality might be reversed. One can imagine a scenario in which monitors hold off on their verdict, violence erupts after elections, and this already occurring violence would lead monitors to condemn the election. I examine this possibility in two ways: with original data on sequencing and with a statistical analysis of reverse causality. As above, I replicate model 4 of Table 1 and allow condemnations to be endogenous to a number of factors (Kelley 2012, 198; see notes for Table A14). The results show that the null hypothesis of exogeneity cannot be rejected (see large p-values for $\mathrm{H}_{0}$ in Table A14). And, as mentioned before, even when accounting for potential endogeneity, condemnation remains significantly associated with a higher risk of violence.

Original data on the temporal order of events also cast doubt on reverse causality. I collected data on the timing of IO reports and the announcement of provisional results in relation to election-day. In order for post-election violence to influence observer reports, the reports need to be issued several days, perhaps weeks after the election to allow time for announced results and responding violence. Yet Figure A1 in the Supplementary Files displays a different story: the vast majority of IO reports are issued within 1-2 days immediately after voting, sometimes even before or on the day of polling itself. Further, IO verdicts almost always precede the announcement of results. When losers challenge results, they tend to wait for results to be announced, which usually takes several days or weeks after voting. Verdicts tend to be announced more quickly (often late on election day or within a couple of days after voting). This makes it difficult for verdicts to be influenced by post-election violence 49 Thus the weight of the evidence discounts endogeneity concerns.

${ }^{49}$ This is consistent with non-African examples where election losers hold off their decision to protest until after the observer verdict. Hyde and Marinov 2014, 352-53. 
A third concern is spuriousness: fraud or other pre-treatment covariates may influence both condemnations (treatment) and violence (outcome). To address this concern, I employ genetic and coarsened exact matching on all observed elections (Diamond and Sekhon 2013; Iacus, King, and Porro 2012). The idea behind matching is to reduce imbalance on pre-treatment confounders between treated and control groups, thus reducing bias in the estimated treatment effect, and approximating a randomized experiment. Matching allows us to compare elections that are effectively similar across a range of structural factors that influence violence but differ in whether or not they have been condemned by reputable observer groups. Matching relies on the assumption of "ignorable treatment assignment." While this assumption cannot be directly tested (Stuart 2010, 15), it is reasonable in this context, I include pre-treatment covariates to reasonably satisfy it, and assess through sensitivity analysis how violating it would affect conclusions. Matching also has limitations (potentially increasing imbalance and only matching on observables; King and Nielsen 2016). A detailed discussion of assumptions (and how they are satisfied) and limitations (and how they are mitigated) is in the Appendix on pages 23-25.

For genetic matching, I first estimate the probability of an election being condemned based on prior research, generating a propensity score 50 Then, elections are matched on this propensity score and all the variables from above (Table 1 model 4) to predict the effect of condemnation on post-election violence. A diagnostic plot (Appendix Figure A3) documents that genetic matching improves covariate balance on all covariates, with differences becoming insignificant between treated and control observations in the matched data. In addition, all standardized differences are smaller than 0.25, a rule-of-thumb for good balance (Stuart 2010, 11-12, 15). The estimated average treatment effect on the treated is 0.35 with a standard error of 0.14 , which is again statistically significant, positive, and comparable in size to the main result. 51 I also use coarsened exact matching (CEM) as alternative; the results are quite similar and detailed in the Appendix. The matching analyses suggests that there is a statistically significant, positive average treatment effect of condemnations on post-election violence. When accounting for potential spuriousness, the main result holds up. Since the matching process pairs elections with similar characteristics, this suggests that condemnations do not simply reflect "bad" elections which would have resulted in violence

\footnotetext{
${ }^{50}$ Again based on Kelley $(2012,198)$ and as in the endogeneity test on Table A14 model 1 stage 1; see notes for Table A15 in the Supplementary Files.

${ }^{51}$ The list of matched pairs is in Table A15. The interpretation is unchanged when using more fine-grained data or also matching on incumbent loss; see Appendix pages 25, 28.
} 
regardless of condemnation. As noted before, fraud alone is less likely to lead to violence than "internationally certified fraud."

Finally, concerns about omitted variables often remain with observational data and with matching procedures. The main analysis (Table 1) includes a rich set of control variables and follow-on analyses add further controls (Tables A6-A9, A10, A16-A18 in the Supplementary Files). For example, it is possible that opposition coalitions during the election or the strategic importance of the country may unduly drive results, so robustness checks include relevant measures as further control variables 52 Other robustness checks control for whether it is the first election monitored by reputable groups (which might be different), whether domestic observers were also present, and restricts attention to only those condemnations that reached the mass public. These tests do not change the substantive result. ${ }^{53}$ Nonetheless, it remains possible that unobserved confounders unduly bias the estimated effect of condemnation on post-election violence. To assess the robustness of the estimates to the presence of omitted variables, I run sensitivity analyses as developed by VanderWeele (2011). The proposed method assumes that some binary variable is omitted from the model used to estimate the effect of condemnation on post-vote violence. The biasing variable may represent some underlying country propensity for social conflict or other unobserved or unobservable factors. The sensitivity analysis is detailed in the Supplementary Files and results are illustrated in Figure A4 in the Supplementary Files. The results suggest that the estimates are robust to strong levels of bias arising from unobserved or unobservable factors. This makes it unlikely that bias from unobserved covariates is fully driving the impact of condemnation on violence.

While any individual robustness test is perhaps not convincing in and of itself (as all modeling approaches have underlying assumptions and weaknesses) the variety of different tests - with results pointing in the same direction - increase confidence in the main finding.

\section{Case Comparison: Sierra Leone vs. Kenya 2007}

${ }^{52}$ Specifically, I control for British or French colonial ties, voting affinity with the US in the UN General Assembly, and aid per capita. Data are sourced from the ICOW Colonial History Data Set; Graham and Tucker 2017; Bailey, Strezhnev, and Voeten 2017. Results are in Appendix Table A19.

${ }^{53}$ Data are sourced from nelda46, V-Dem, nelda28. Results are in Appendix Tables A2022 . 
This section compares two elections to illustrate the mechanism linking condemnations and violence, i.e. increasing the loser's incentives to challenge the result by (i) indicating that the loser has more popular support than the official result suggests and (ii) providing a focal point for mobilization. The pair of cases - Kenya vs. Sierra Leone 2007 - is drawn from the matching analysis (Table A15). Thus the elections were effectively similar along the structural variables influencing post-election violence: both were general elections with 4-8 years of leader tenure, low pre-election violence, serious fraud, and about $45 \%$ vote share for the loser. In addition to these control variables, the two elections were also similar in other respects. Both countries were former British colonies and gained independence in early 1960s, followed by periods of dominant-party rule and then (again) multi-party elections in 2002. Both countries were presidential systems and had a history of coups and experience with violence in previous elections, as well as substantial ethnic diversity and ethnicity as a relevant factor. While the comparison is not perfect, it is certainly instructive. Since the two elections were effectively similar along the control variables (see Table A23 in the Supplementary Files) and other dimensions, alternative explanations have limited explanatory leverage for why Sierra Leone remained peaceful while Kenya erupted in intense violence. If anything, we might expect Sierra Leone to be more violent due to its civil war history, lower development, and higher share of ethnically excluded population.

A crucial difference between the cases was the observer verdict: the EU endorsed the election in Sierra Leone but condemned the one in Kenya. Tensions were high after Sierra Leone's presidential runoff, with ballot stuffing and disrupted vote counts leading to claims of fraud, weapons movements, further mobilization of ex-combatants, and getting machetes ready to attack opponents (Njanji 2007; Christensen and Utas 2008, 515, 536-537). The next day, however, EU observers issued a preliminary statement endorsing the election result as "generally well administered" (European Union 2007, 1, 7). This positive verdict confirmed the credibility of the election result, an incumbent party loss.54 Weak domestically and deprived of a condemnation to use as a rallying cry, the loser conceded defeat the same day on which results were announced so that post-vote violence did not occur.

This stands in sharp contrast to Kenya's election a few months later, which EU observers condemned. This condemnation unintentionally helped embolden the loser to challenge the result violently. In Kenya, some election officials initially kept local results secret, which the EU chief observer criticized as "clearly disturbing" (Gettleman 2007a). Notably, the

${ }^{54}$ Incumbent loss is not significantly associated with post-vote violence in multi-variate analyses (see Table A14) or bi-variate analyses (probability $($ chi2 $)=0.74$ ). 
EU observer group publicly condemned the election on December 30, before final results were announced and before widespread violence erupted 55 Early on December 30, when the results were "still up in the air," the EU chief observer cast serious doubt on election credibility noting the lack of transparency and suspiciously high turnout in some areas (Ibid). As discussed in the theory section, one condemnation from a reputable observer (here the $\mathrm{EU}$ ) is often sufficient to contribute to violence. In fact, some say that the EU statement was the "most damning" as it was "the largest international observer group, which documented a number of startling verified irregularities" (Cheeseman 2008, 176). The EU, too, thinks that its observer statements are "more influential in shaping perceptions" because the EU is often the largest observation mission (Atwood 2012, 22).

The EU condemnation was repeated in several international media outlets on December 30, such as in South African Mail, New York Times, Irish Times. Kenyans could access various international outlets and increasingly had to, as the government suspended live news broadcast with the exception of a government-backed station (Kenya Broadcasting Corporation; see Rambaud 2008, 98). Observer condemnation reached broad sections of society: "Popular vindication built up as more and more signs of manipulation were denounced by ODM as well as European Union and Commonwealth observers, followed by local NGOs and some ECK commissioners. News and rumors about the rigging sparked off events" (Lafargue and Katumanga 2008, 14).

While other reputable observer groups eventually also criticized election quality, meaning that observers were "near unanimous that vote counting in the 2007 elections was flawed" (Gibson and Long 2009, 499), the EU was the first to criticize the election on December 30 (Gettleman 2007a; Gettleman 2007b) 56 The EU re-iterated its criticism on December 31 and January 1 (Gettleman 2007c; European Union 2008).

${ }^{55}$ Early unrest before December 30 was quite different from subsequent violence in motivation (protests against delaying the results), intensity (limited "scuffles" and property damage), and geographic scope (Nairobi slums). This contrasts sharply with the intense and widespread violence across the country that erupted after the condemnation and final results announcement. See International Crisis Group 2008, 9; United Nations 2008, 8; Gettleman 2007a.

${ }^{56}$ The IRI, the Commonwealth, and other observer groups praised voting and first withheld judgement on counting (see IRI, 28 December 2007). Later they also condemned the election due to irregularities in counting. The IRI condemned the election on January 2; Commonwealth and COMESA criticized it later in January. 
However, "despite the protestations of the ODM and the EU that irregularities in the results had not been sufficiently investigated" the election commission declared Kibaki the winner. (Cheeseman 2008, 176). When results were announced later on December 30, supporters of the electoral loser (Odinga) immediately challenged them by attacking the homes and businesses of the winner's (Kibaki) supporters. The winner "tried to pre-empt any [further] challenge by having himself hurriedly sworn in" (Human Rights Watch 2008, 22). Within a few hours, the EU chief observer followed up on the earlier EU criticism, noted inconsistencies between local and national results, and stated that the tallying process was not credible (Gettleman 2007b) so that "doubt remains as to the accuracy of the result announced today" (Daily Nation 2007; European Union 2008, 1).

The observer condemnation made it more difficult to portray the opposition as sore losers. The Kenyan press linked the observer condemnation directly to the loser challenge: Odinga's "charges of fraud were lent extra weight by the EU election monitoring team" (Daily Star 2008, Bosire 2008.) The loser called for mass protest, which the supporters were ready to join (ABC Premium News 2008). Odinga supporters, even abroad, felt that that Odinga's decision not to accept the election was justified by observer criticism (Butty 2008). Foreign observer criticism "strengthened the opposition in officially contesting the results without offering an alternative" (Connan 2008, 329). The United Nations later noted that "based on the findings of various observation missions and independent reports, however, it is clear that procedural irregularities in the vote counting and tallying cast serious doubts on the legality of the election results. Kenyan voters who did not support Kibaki and who felt they had been deprived of their basic democratic rights then unleashed a wave of protests and violence that engulfed the country for weeks" (United Nations 2008, 15). In short, it was after observer criticism and the announcement of final results that the loser challenged the result, unrest escalated and spiraled into widespread and intense violence across the country, with over 1,000 fatalities and many more injured and displaced. While observer criticism did not cause initial clashes over results delay, it contributed to the escalation of violence after results announcement.

Furthermore, the EU later acknowledged the role that its negative report played: it "may have reinforced the narrative (of a vote stolen by the election commission on behalf of President Kibaki) which was driving violence" (Atwood 2012, 22). In addition to the EU, the IRI observers also seemed to be aware of the condemnation-violence link 57 Odinga attached

${ }^{57}$ The IRI withheld its own exit poll, which showed the official "loser" (Odinga) winning. It would likely also have contributed to a loser challenge of results and potentially fueled 
high value to observer findings. Regarding the IRI poll, Odinga said that "my [Odinga's] supporters believe that had IRI released those polls, they would have made a huge difference" (McIntyre and Gettleman 2009). This shows that international observer statements are important to the election candidates and the (announced) loser in particular. Thus, observer condemnation exacerbated post-election violence in Kenya. Clearly, observer condemnation mattered; it was one important factor - although not the only factor - contributing to post-election violence.

Taken together, this evidence supports both parts of the mechanism. First, the EU's criticism of the election result suggested that Odinga's popular support was larger than Odinga's official vote share. And second, this condemnation was an important factor contributing to the narrative of a stolen election and thereby facilitating mobilization among Odinga's supporters.

\section{Conclusion}

Studies of international election monitoring have generally highlighted its positive effects, and critical observer reports specifically have been lauded for increasing international pressure for democratization and potentially stimulating domestic reform (Donno 2010; Hyde and Marinov 2014). Yet the same observer condemnations can also trigger violence. A negative IO report can increase the electoral loser's incentives to challenge results by indicating that the loser's popular support is larger than the official vote share and by providing a focal point for mobilization. Loser challenges can themselves be violent or provoke reactionary repression, resulting in violent intimidation and fatalities. These findings suggest that IO observers may not have unequivocally positive effects, but can also have significant negative side effects that contribute to violence.

This study documents for the first time the potentially violent consequences of observer condemnations and disentangles the effect of observer criticism from the effects of observer presence and election fraud. Previous work examined the effect of observer presence on conflict, and the effect of observer condemnation on protest, which may or may not be violent - but left unclear whether condemnation also drives post-election violence. Using data on post-election violence for 38 countries in sub-Saharan African since 1990, the analyses show that condemnation can increase the risk of post-vote violence. This finding is robust to different samples, report nuances, different measures of fraud and other control variables,

violence; see McIntyre and Gettleman 2009. 
and to accounting for potential selection, omitted variables, spuriousness, and endogeneity. The results show that condemnations can contribute to post-election violence, even after controlling for a wide range of factors. I also draw on original data on the timing of IO verdicts and results, data about loser challenges, and a comparative case study to trace the dynamics in more detail. The analyses also provide support for the proposed causal chain, i.e. that condemnations make loser challenges more likely, which in turn are associated with more post-vote violence.

One question for future research is whether this dynamic is limited to Africa. As sufficiently granular data on electoral violence become available for other regions, we can explore these dynamics systematically in other contexts. It is possible that the condemnationviolence link is weaker outside of Africa because of higher strategic importance or stronger democratic institutions. For example, countries in Latin America or the Middle East might be seen as more strategically important (for the US or Europe), which could make observers less likely to condemn elections or make preventive or crisis diplomacy more likely, leading to a lower risk of post-vote violence. It is also possible that regions with stronger democratic institutions - including more credible election commissions and higher quality elections have less uncertainty about election credibility, so that the added informational value from election observers is lower. Future research is needed to systematically assess this dynamic in other parts of the world, but several cases suggest that the argument's logic might also travel to other regions.

A purview of cases suggests that similar dynamics have also emerged in other regions. For example, while Mexico's 1994 election was hailed as a step forward, monitors criticized the uneven playing field in terms of media coverage and financing. The electoral loser (Cardenas) repeated this criticism almost verbatim as the motivation for challenging the outcome (Fineman 1994). Panama's 1989 election went sour when dictator Noriega's favorite candidate was trailing the vote count; Noriega replaced tally sheets and then annulled the election. As international observer, former President Carter personally criticized this move, and the opposition followed with mass protests the next day, at which the main opposition leader (Endara) was severely beaten by paramilitary forces (NDI/IRI 1989, v, 79). In Jordan, 2010 was the first election to be criticized by international observers and also the first to erupt in peaceful mass protests, with the government using tear gas to disperse crowds. Similarly, Azerbaijan's 2003 election was condemned by monitors and then challenged by the losing opposition, leading to mass arrests and at least one fatality from clashes with the police (Anderson et al. 2005, 6). Armenia's 1996 election was followed by peaceful protests 
which turned violent after the OSCE condemned the elections (Bennett 1996). These and other cases suggest that the conclusions also apply to some elections beyond Africa, but more systematic analyses are needed.

Another interesting question is whether the political violence (or protests or revolutions) that can result from condemnations can nevertheless contribute to democratization. While rich literatures have emerged on democratization and political violence - as well as the role of international actors in these domestic processes - they have largely developed independent of one another. Whether and to what extent democratization actually ensues after election violence or even non-violent protests is an open empirical question. Short of systematic studies, election violence seems undesirable because peaceful elections are a cornerstone of democracy, because short-term consequences of violence are rarely positive (such as leadership or regime change), and because long-term consequences are usually detrimental for legitimacy, development, and broader stability (Bratton 2008; Bekoe 2012).

From a policy perspective, the potentially negative consequences of condemnations have important implications for international election assistance. Observer groups should - first and foremost - fulfill their mandate, which is monitoring and publicly assessing the election quality. Not doing so would defeat the observers' purpose, diminish their value added, and seriously call into doubt their long-term vitality. However, there might be ways to mitigate the observer dilemma. First, IOs could avoid attending clearly undemocratic elections and explicitly state the reasons. While most reputable monitoring IOs have agreed to avoid undemocratic elections (United Nations 2005, 4), this strategy has not been fully implemented. "Elections" in Cambodia 2008, Azerbaijan 2010, Kazakhstan 2011, Cameroon 2011, Swaziland 2013, and Uzbekistan in 2014 were all observed by credible IOs. There was little evidence before-hand that these elections would be fair. By attending elections which have already been rigged in the pre-election period, observer groups risk lending legitimacy to undemocratic processes.

Second, (more) observer groups could issue more frequent interim statements before election day to lower the impact of a sudden condemnation. Instead of the first critical statement "hitting" immediately after voting, when tensions are high, observer groups could issue preliminary press statements regularly in the weeks leading up to polling. By slowly adjusting expectations and reflecting political conditions as they evolve, the impact of the condemnation might be lessened.

Third, donor agencies and democracy promotion IOs may be well advised to consider a shift from observation to technical assistance for some elections. If violence breaks out 
because election results are not credible, then one solution is to strengthen electoral institutions to support credible elections (von Borzyskowski 2019). Instead of expending resources to establish that undemocratic elections were indeed not meaningful, donor organizations could support reforms, such as strengthening election institutions, and conducting voter education. Since technical assistance (Ludwig 2004; von Borzyskowski 2016) does not publicly judge election credibility, its potential for stirring unrest is lower. If anything, technical assistance may help secure the loser's consent or peaceful engagement by increasing the credibility of the electoral process. 


\section{References}

$A B C$ Premium News. 2008. "Kenya under pressure as death toll rises," 1 January 2008. https://www.abc.net.au/news/2008-01-01/ kenya-under-pressure-as-death-toll-rises/1000344

Abouharb, Rodwan, and David Cingranelli. 2006. "The Human Rights Effects of World Bank Structural Adjustment, 1981-2000.” International Studies Quarterly 50(2):233-262.

"African Elections Database," accessed 20 July 2018, http://africanelections.tripod. com/

Alvarez, Michael, Thad Hall, and Susan Hyde. 2008. Election Fraud: Detecting and Deterring Electoral Manipulation. Washington, D.C.: Brookings Institution Press.

Anderson, Christopher, Andre Blais, Shaun Bowler, Todd Donovan, and Ola Listhaug. 2005. Losers' Consent: Elections and Democratic Legitimacy. Oxford, UK: Oxford University Press.

Arriola, Leonardo, and Chelsea Johnson. 2012. "Election Violence in Democratizing States," accessed 20 July 2018, http://pscourses.ucsd.edu/poli120n/ArriolaJohnson2012. pdf

Atwood, Richard. 2012. How the EU can Support Peaceful Post-Election Transitions of Power: Lessons from Africa. Brussels, Belgium: European Union. Available at http://www.europarl.europa.eu/RegData/etudes/note/join/2012/457110/ EXPO-AFET_NT (2012) 457110_EN.pdf

Bailey, Michael, Anton Strezhnev, and Erik Voeten. 2017. "Estimating Dynamic State Preferences from UN Voting Data." Journal of Conflict Resolution 61(2):430-456.

Beaulieu, Emily. 2014. Electoral Protest and Democracy in the Developing World. Cambridge, UK: Cambridge University Press.

Beaulieu, Emily, and Susan Hyde. 2009. "In the Shadow of Democracy Promotion: Strategic Manipulation, International Observers, and Election Boycotts." Comparative Political Studies 42(3):392-415.

Beck, Thorsten, George Clarke, Alberto Groff, Philip Keefer, and Patrick Walsh. 2001. "New tools in comparative political economy: The Database of Political Institutions." World Bank Economic Review 15(1):165-176.

Beissinger, Mark. 2007. "Structure and Example in Modular Political Phenomena: The Diffusion of Bulldozer/Rose/Orange/Tulip Revolutions." Perspectives on Politics 5:259276.

Bekoe, Dorina. 2012. Voting in Fear. Washington, D.C.: USIP. 
Bennett, Vanora. 1996. "Armenian Protests Turn Violent," LA Times, 26 September 1996. http://articles.latimes.com/1996-09-26/news/mn-47818_1_armenian-protests

Bjornlund, Eric 2004. Beyond Free and Fair. Monitoring Elections and Building Democracy.

Washington, D.C.: Woodrow Wilson Center Press.

Bjornlund, Eric, Michael Bratton, and Clark Gibson. 1992. "Observing Multiparty Elections

in Africa: Lessons from Zambia." African Affairs 91: 405-31.

Bosire, Bogonko. 2008. "EU says Kenya poll flawed, death toll nears 260," Daily Star,

2 January 2008. https://infoweb-newsbank-com.proxy.lib.fsu.edu/apps/news/ document-view? $p=A W N B \& d o c r e f=n e w s / 11 D E D 87 B F 21741 E 8$

von Borzyskowski, Inken. 2019. The Credibility Challenge: How Democracy Aid Influences

Election Violence. Ithaca, NY: Cornell University Press.

von Borzyskowski, Inken. 2016. "Resisting Democracy Assistance: Who Seeks and Receives

Technical Election Assistance?" Review of International Organizations 11(2):247-282.

von Borzyskowski, Inken, and Michael Wahman. 2019. "Systematic Measurement Error in

Election Violence Data: Causes and Consequences." British Journal of Political Science.

Bubeck, Johannes, and Nikolay Marinov. 2017. "Process or Candidate: The International

Community and the Demand for Electoral Integrity." American Political Science Review 111(3):535-554.

Bunce, Valerie, and Sharon Wolchik. 2010. "Defeating dictators: Electoral Change and Stability in Competitive Authoritarian Regimes." World Politics62:43-86.

Bush, Sarah, and Lauren Prather. 2017. "The Promise and Limits of Election Observers in Building Election Credibility." Journal of Politics 79(3):921-935.

Bush, Sarah, and Lauren Prather. 2018. "Who's There? Election Observer Identity and the Local Credibility of Elections." International Organization 72:659-92.

Butty, James. 2008. "Kenyans in U.S. Protest Disputed Election Results," Voice of America, 3 January 2008. http://m. voanews. com/a/565862.html

Carothers, Thomas. 1997. "The Observers Observed." Journal of Democracy 8(3):17-31.

Carr, Adam. "Election Archive," accessed 20 July 2018, http://psephos.adam-carr.net/

Chacon, Mario, James Robinson, and Ragnar Torvik. 2011. "When is Democracy and Equilibrium? Theory and Evidence from Colombia's La Violencia." Journal of Conflict Resolution 55(3):366-396.

Cheeseman, Nic. 2008. "The Kenyan Elections of 2007: An Introduction." Journal of Eastern African Studies 2(2):166-184

Chernykh, Svitlana, and Milan Svolik. 2015. "How Electoral Commissions, Courts, and Ob- 
servers Shape Incentives for Electoral Manipulation and Post-Election Protests." Journal of Politics 77(2):407-420.

Christensen, Maya, and Mats Utas. 2008. "The 'politricks' of remobilized combatants in the 2007 general elections, Sierra Leone." African Affairs 107(429):515-539.

Collier, Paul. 2009. Wars, Guns and Votes: Democracy in Dangerous Places. New York, NY: Harper Collins.

Connan, Dominique. 2008. "The human rights civil society. Social powerlessness and the quest for political legitimacy." Journal on East Africa 38: 317-348.

Daily Nation. 2007. "Violence erupts after Kibaki sworn in," 31 December 2007. https: //www.nation.co.ke/news/1056-224116-lu3osez/index.html

Daily Star. 2008. "Kenya polls flawed: EU," 2 January 2008. http://archive. thedailystar.net/newDesign/news-details.php?nid=17404

Daxecker, Ursula. 2012. "The Cost of Exposing Cheating: International Election Monitoring, Fraud, and Post-Election Violence in Africa." Journal of Peace Research 49(4):503516 .

Diamond, Alexis, and Jasjeet Sekhon. 2013. "Genetic Matching for Estimating Causal Effects: A General Multivariate Matching Method for Achieving Balance in Observational Studies." Review of Economics and Statistics 95(3):932-945.

Donno, Daniela. 2013. Defending Democratic Norms: International Actors and the Politics of Electoral Misconduct. Oxford, UK: Oxford University Press.

Donno, Daniela. 2010. "Who is Punished? Regional Intergovernmental Organizations and the Enforcement of Democratic Norms." International Organization 64(3):593-625.

European Union Election Observation Mission. 2007. "Republic of Sierra Leone, Second Round of the Presidential Elections, 8-September-2007, Statement of preliminary findings and conclusion, 10-Sept-2007." Available at http://eeas.europa.eu/archives/eueom/ $\mathrm{pdf} / \mathrm{missions} / \mathrm{pr} \_$eueomsl_10_8.pdf

European Union Election Observation Mission. 2008. "Preliminary Statement: Doubts about the Credibility of the Presidential Results Hamper Kenya's Democratic Progress, 1-Jan-2008." Available at http://eeas .europa.eu/eueom/pdf/missions/kenya_2007_ final_preliminary_statement.pdf

Fearon, James, and David Laitin. 2003. "Ethnicity, insurgency, and civil war." American Political Science Review 9 (1):75-90.

Fineman, Mark. 1994. "70,000 Rally in Mexico to Protest Vote Fraud," LA Times, 28 August 1994. http://articles.latimes.com/1994-08-28/news/mn-32252_1_vote-fraud 
Finkel, Steven, Anibal Perez-Linan, and Mitchell Seligson. 2007. "The Effects of U.S. Foreign Assistance on Democracy Building, 1990-2003." World Politics 59:404-439.

Fischer, Jeff. 2002. "Electoral Conflict and Violence: A Strategy for Study and Prevention." Available at http://www .ifes.org/sites/default/files/econflictpaper.pdf

Flores, Thomas. 2012. "Monitoring the Monitors: Understanding Election Observation in Today's World." International Studies Review 15(3):432-437.

Flores, Thomas, and Irfan Nooruddin. 2012. "The Effect of Elections on Postconflict Peace and Reconstruction." Journal of Politics 74(2):558-570.

Gandhi, Jennifer, and Ellen Lust-Okar. 2009. "Elections Under Authoritarianism." American Review of Political Science 12:403-22.

Garber, Larry, and Glenn Cowan. 1993. "The Virtues of Parallel Vote Tabulation." Journal of Democracy 4(2):95-107.

Gettleman, Jeffrey. 2007a. "Riots Batter Kenya as Rivals Declare Victory." New York Times, 30 December 2007. https://www.nytimes.com/2007/12/30/world/africa/30kenya. html

Gettleman, Jeffrey. 2007b. "Tribal Rivalry Boils Over After Kenyan Election." New York Times, 30 December 2007. https://www.nytimes.com/2007/12/30/world/africa/ 30cnd-kenya.html

Gettleman, Jeffrey. 2007c. "Disputed Vote Plunges Kenya Into Bloodshed," New York Times, 31 December 2007. https://www.nytimes.com/2007/12/31/world/africa/ 31kenya.html

Gibson, Clark, and James Long. 2009. "The presidential and parliamentary elections in Kenya, December 2007." Electoral Studies 28(3):497-502.

Graham, Ben, and Jacob Tucker. 2017. "International Political Economy Data Resource." Review of International Organization. Version 1.5.

Gleditsch, Nils Petter, Peter Wallensteen, Mikael Eriksson, Margareta Sollenberg, and Havard Strand. 2002. "Armed Conflict 1946-2001: A New Dataset." Journal of Peace Research 39(5):615-637.

Hafner-Burton, Emilie, Susan Hyde, and Ryan Jablonski. 2014. "When do Governments Resort to Election Violence?" British Journal of Political Science 44(1):149-179.

Hartzell, Caroline, Matthew Hoddie, and Molly Bauer. 2010. "Economic Liberalization via IMF Structural Adjustment: Sowing the Seeds of Civil War?" International Organization 64(2):339-356.

Human Rights Watch. 2008. "Ballots to Bullets: Organized Political Violence and Kenya's 
Crisis of Governance." Human Rights Watch 20(1A). https://www.hrw.org/reports/ 2008/kenya0308/kenya0308web.pdf

Hyde, Susan. 2007. "The Observer Effect in International Politics. Evidence from a Natural Experiment." World Politics 60:37-63.

Hyde, Susan. 2011. The Pseudo-Democrat's Dilemma. Why election monitoring became an international norm. Ithaca, NY: Cornell University Press.

Hyde, Susan. 2012. Why believe international election monitors? In The Credibility of Transnational NGOs, edited by Gourevitch, Lake, Stein, 37-61. New York, NY: Cambridge University Press.

Hyde, Susan, and Nikolay Marinov. 2012. "Which Elections can be lost?" Political Analysis 20(2):191-210.

Hyde, Susan, and Nikolay Marinov. 2014. "Information and Self-Enforcing Democracy: The Role of International Election Observation." IO 68(2):329-359.

Hyde, Susan, and Angela O'Mahony. 2010. "International Scrutiny and Pre-Electoral Fiscal Manipulation in Developing Countries." Journal of Politics 72(3):1-14.

Iacus, Stefano, Gary King, and Giuseppe Porro. 2012. "Causal Inference Without Balance Checking: Coarsened Exact Matching." Political Analysis 20(1):1-24.

Ichino, Nahomi, and Matthias Schündeln. 2012. "Deterring or Displacing Electoral Irregularities?" Journal of Politics 74(1):292-307.

International Crisis Group. 2008. "Kenya in Crisis. Africa Report no 137." Available at https://www.crisisgroup.org/africa/horn-africa/kenya/kenya-crisis

Institute for Security Studies. 2017. "Elections in 2017: can the AU up its game?" Available at https://issafrica.org/iss-today/ elections-in-2017-can-the-au-up-its-game

Kelley, Judith. 2009. "D-Minus Elections: The Politics and Norms of International Election Observation." International Organization 63: 765-87.

Kelley, Judith. 2010. Data on International Election Monitoring: Three Global Datasets on Election Quality (QED), Election Events and International Election Observation (DIEM). Available at https://www.icpsr.umich.edu/icpsrweb/ICPSR/studies/ 31461/version/1

Kelley, Judith. 2012. Monitoring Democracy: When International Election Observation Works, and Why It Often Fails. Princeton, NJ: Princeton University Press.

King, Gary, and Richard Nielsen 2016. "Why Propensity Scores Should Not Be Used for Matching." Working Paper. Available at https://gking.harvard.edu/publications/ 
why-propensity-scores-should-not-be-used-formatching

King, Gary, Michael Tomz, and Jason Wittenberg. 2000. "Making the Most of Statistical Analyses: Improving Interpretation and Presentation." American Journal of Political Science 44(2):347-61.

Krieger, Norma. 2005. "ZANU(PF) strategies in general elections, 1980-2000: discourse and coercion." African Affairs 104(414).

Kuntz, Philipp, and Mark Thompson. 2009. "More than just the Final Straw: Stolen Elections as Revolutionary Triggers." Comparative Politics 41(3):253-272.

Kuran, Timur. 1995. Private Truths, Public Lies: The Social Consequences of Preference Falsification. Cambridge: Harvard University Press.

Laakso, Liisa. 2009. "Insights to Electoral Violence in Africa." In Votes, Money and Violence: Political Parties and Elections in Sub-Saharan Africa. Kwazulu-Natal Press, 224-252.

Lindberg, Staffan. 2006. Democracy and Elections in Africa. Johns Hopkins University Press. Dataset for 1989-2007 accessed July 20, 2018. http://users.clas.ufl.edu/ sil/downloads.html

Londregan, John, and Andrea Vindigni. 2006. Voting as a Credible Threat. https://rppe. princeton $. e d u / f i l e / 776 / d o w n l o a d ? t o k e n=8 E o I d r \_7$

Ludwig, Robin. 2004. "The UN's Electoral Assistance. Challenges, Accomplishments, and Prospects." In The UN Role in Promoting Democracy, 169-187. New York, NY: UN University Press.

Luo, Zhaotian, and Arturas Rozenas. 2017. "The Election Monitor's Curse." American Journal of Political Science 62(1):148-160.

Magaloni, Beatriz. 2010. "The Game of Electoral Fraud and the Ousting of Authoritarian Rule." American Journal of Political Science 54(3): 751-765.

Makumbe, John. 2002. "Zimbabwe's Hijacked Election." Journal of Democracy 13(4):87-101.

Masunungure, Eldred. 2011. "Zimbabwe's Militarized, Electoral Authoritarianism." Journal of International Affairs 65(1):47-64.

Marshall, Monty, and Keith Jaggers. 2011. Polity IV Project. Dataset User's Manual.University of Maryland, College Park.

McCoy, Jennifer, Larry Garber, and Robert Pastor. 1991. "Pollwatching and Peacemaking." Journal of Democracy 2(4):102-114.

McIntyre, Mike and Jeffrey Gettleman. 2009. "A Chaotic Kenya Vote and a Secret US Exit Poll," New York Times, 31 January 2009. https://www.nytimes.com/2009/01/ 31/world/africa/31kenya.html 
Mehler, Andreas. 2007. "Political Parties and Violence in Africa: Systematic Reflections against Empirical Background," In Votes, Money and Violence, edited by Matthias Basedau, Gero Erdmann and Andreas Mehler, 194-223. Scottsville, South Africa: University of Kwazulu-Natal Press.

Moehler, Devra. 2009. "Critical Citizens and Submissive Subjects: Election Losers and Winners in Africa." British Journal of Political Science 39: 345-366.

Nadeau, Richard, and Andre Blais. 1993. "Accepting the Election Outcome: The Effect of Participation on Losers' Consent." British Journal of Political Science 23(4): 553-563.

NDI/IRI. 1989. The 7 May 1989 Panamanian Elections. https://www. cartercenter.org/ documents/electionreports/democracy/FinalReportPanama1989.pdf

Nevitte, Neil, and Santiago Canton. 1997. "The Role of Domestic Observers." Journal of Democracy 8(3).

Njanji, Susan. 2007. "Ballot counting on amid tension in SLeone presidential run-off," Agence France Press, 9 September 2007. https://infoweb-newsbank-com.proxy.lib. fsu .edu/apps/news/document-view?p=AWNB\&docref=news/11B8EDDB1E40A8D0

Nohlen, Dieter, Michael Krennerich, and Bernhard Thibaut. 1999. Elections in Africa: A Data Handbook. New York, NY: Oxford University Press.

Przeworski, Adam. 1991. Democracy and the Market. Cambridge, UK: Cambridge University Press.

Rambaud, Brice. 2008. "Caught between information and condemnation. The Kenyan media in the electoral campaigns of December 2007." Journal on East Africa 38: 57-108.

Risse, Thomas, and Nelli Babayan. 2015. "Democracy promotion and the challenges of illiberal regional powers." Democratization 22(3):381-399.

Riker, William. 1983. "Political Theory and the Art of Heresthetics." In Political Science: The State of the Discipline, edited by Ada Finifter, 47-67. Washington, D.C.: APSA.

Robertson, Graeme. 2017. "Political Orientation, Information and Perceptions of Election Fraud: Evidence from Russia." British Journal of Political Science 47(3):589-608.

Ross, Michael. 2012. The Oil Curse. Princeton, NJ: Princeton University Press.

Schedler, Andreas. 2002. "Elections without Democracy: The Menu of Manipulation." Journal of Democracy 13(2):36-50.

Simpser, Alberto. 2013. Why Governments and Parties Manipulate Elections: Theory, Practice, and Implications. New York, NY: Cambridge University Press.

Simpser, Alberto, and Daniela Donno. 2012. "Can International Election Monitoring Harm Governance?" Journal of Politics 74(2):501-513. 
Smidt, Hannah. 2016. "From a perpetrator's perspective: International election observers and post-electoral violence." Journal of Peace Research 53(2):226-241.

von Soest, Christian, and Michael Wahman. 2015. "Not all dictators are equal: Coups, fraudulent elections, and the selective targeting of democratic sanctions." Journal of Peace Research 52(1):17-31.

Straus, Scott, and Charlie Taylor. 2012. "Democratization and Electoral Violence in SubSaharan Africa, 1990-2008." In Voting in Fear: Electoral Violence in Sub-Saharan Africa, edited by Dorina Bekoe, 15-38. Washington, DC: USIP Press.

Stuart, Elizabeth. 2010. "Matching Methods for Causal Inference: A Review and a Look Forward." Statistical Science 25(1):1-21.

Taylor, Charlie, Jon Pevehouse, and Scott Straus. 2017. "Perils of Pluralism: Electoral violence and incumbency in Sub-Saharan Africa." Journal of Peace Research 54(3):397411.

Tucker, Joshua 2007. "Enough! Electoral fraud, collective action problems, and postCommunist colored revolutions." Perspectives on Politics 5(3):535-51.

United Nations. 2005. "Declaration of Principles for International Election Observation" and "Code of Conduct for International Election Observers." New York.

United Nations Office of the High Commissioner for Human Rights. 2008. "Report from OHCHR Fact-finding Mission to Kenya, 6-28 February 2008." Available at https://www. ohchr.org/documents/press/ohchrkenyareport.pdf

VanderWeele, Tyler. 2011. "Sensitivity Analysis for Contagion Effects in Social Networks." Sociological Methods and Research 40(2):240-255.

Wilkinson, Steven. 2004. Votes and Violence. Cambridge, UK: Cambridge University Press. 